\title{
Morphology Reference Identifier
}

National Cancer Institute

\section{Source}

National Cancer Institute. Morphology Reference Identifier. NCI Thesaurus. Code C117603.

A character or string used to name, or characterize a morphology reference. 